\title{
MUTASI TITIK F1534C GEN VOLTAGE GATED SODIUM CHANNEL (VGSC) PADA Aedes aegypti DI KELURAHAN PANCUR PUNGAH
}

\author{
Fadjar Sidiq Hidayahtullah', Chairil Anwar², dan Dwi Handayani² \\ ${ }^{1}$ Mahasiswa BKU Parasitologi, Program Studi Biomedik, Fakultas Kedokteran, Universitas Sriwijaya, \\ 2Dosen BKU Parasitolofi Program Studi Biomedik, Fakultas Kedokteran, Universitas Sriwijaya, JI.Raya \\ Palembang-Prabumulih KM 32 Indralaya, Ogan Ilir \\ Email: fchapuchinno@yahoo.com
}

\begin{abstract}
Background: The incidence of dengue hemorrhagic fever (DHF) has increased significantly throughout the world in the last decade. One of the challenges in eradicating DHF is the occurrence of vector resistance to insecticides. This study aimed to looked at the mutation site of the VGSC codon F1534C Aedes aegypti on RT 5 \& 6 Pancur Pungah Village, Muara Dua District, Ogan Komering Ulu Selatan Regency as a marker of resistance.

Methods: The samples in this studied were larvae and pupae of Aedes aegypti. Larvae and pupae were bred into F1 generation and then tested for susceptibility and followed by polymerase chain reaction (PCR).

Result: The results of the suscepbillity test carried out obtained mosquito mortality of $10.5 \%$ so it was categorized resistant based on WHO criteria. Continued PCR test found no mutation point occurred in the VGSC gene mutation point F1534C in Aedes aegypti. Therefore, the possibility of mutations in the VGSC gene is at another mutation point.
\end{abstract}

Keyword: Mutation, Aedes aegypti, F1534C

\begin{abstract}
ABSTRAK
Latar Belakang: Kejadian demam berdarah dengeu (DBD) telah meningkat signifikan di seluruh dunia dalam dekade terakhir. Salah satu tantangan dalam pemberantasan DBD adalah kejadian resistensi vektor terhadap insektisida. Penelitian ini bertujuan untuk melihat titi mutasi gen VGSC kodon F1534C Aedes aegypti di RT 5 \& 6 Kelurahan Pancur Pungah Kecamatan Muara Dua Kabupaten Ogan Komering Ulu Selatan sebagai penanda terjadinya resistensi.
\end{abstract}

Metode: Sampel pada penelitian ini adalah larva serta pupa nyamuk Aedes aegypti. Larva dan pupa dibiakkan menjadi generasi F1 lalu dilakukan uji suscepbillity dan dilanjutkan uji polymerase chain reaction (PCR).

Hasil: Hasil penelitian pada uji suscepbillity yang dilakukan didapat kematian nyamuk sebesar 10,5\% sehingga dikategorikan resisten berdasarkan kriteria WHO. Dilanjutkan uji PCR didapat tidak terjadi titik mutasi pada gen VGSC mutasi titik F1534C pada Aedes aegypti. Oleh karena itu, kemungkinan terjadinya mutasi pada gen VGSC berada pada titik mutasi yang lain.

Kata kunci: Mutasi, Aedes aegypti, F1534C 


\section{Pendahuluan}

Penyakit demam berdarah dengue (DBD) merupakan penyakit yang sangat mudah ditemukan di daerah tropis. DBD ditularkan oleh gigitan nyamuk Aedes aegypti kepada manusia. Banyak reaksi yang ditimbulkan salah satunya pendarahan dan syok sehingga menyebabkan angka kematian menjadi cukup tinggi. ${ }^{13}$

Kejadian DBD telah meningkat secara dramatis di seluruh dunia dalam beberapa dekade terakhir. Jumlah kasus yang dilaporkan meningkat dari 2,2 juta pada 2010 menjadi 3,2 juta pada 2015. Satu perkiraan baru-baru ini menunjukkan 390 juta infeksi DBD per tahun. Pada tahun 2018, DBD juga dilaporkan dari Bangladesh, Kamboja, India, Myanmar, Malaysia, Pakistan, Filipina, Thailand, dan Yaman. Diperkirakan 500.000 orang dengan DBD berat memerlukan rawat inap setiap tahun, dan dengan perkiraan $2,5 \%$ kasus kematian, setiap tahun. ${ }^{20}$ Sedangkan di Indonesia angka DBD sejak tahun 1968 telah terjadi peningkatan jumlah kasus DBD, pada tahun 1968 hanya 58 kasus menjadi 158.912 kasus pada tahun $2009 .^{7}$ Hal ini diperkuat dengan kejadian penyakit DBD per 1 Februari 2019 tercatat 15.132 kasus dengan angka kematian mencapai 145 jiwa di seluruh Indonesia. Provinsi dengan kasus DBD dan kematian akibat DBD paling tinggi saat ini adalah Provinsi Jawa Timur dengan 3.074 kasus dan 52 kematian. ${ }^{5}$ Untuk Sumatera Selatan tercatat 1449 kasus DBD dengan angka kematian 7 kasus. $^{1}$ Sampai dengan Februari 2019, menurut Direktur Penyakit Tular Vektor dan Zoonotik Kemenkes tercatat 11,280 kasus DBD di 22 provinsi di Indonesia dan beberapa diantaranya berstatus Kejadian Luar Biasa (KLB). Dengan angka kematian sebesar 110 jiwa, Indonesia termasuk kategori darurat DBD. Dinas Kesehatan Provinsi Sumatera Selatan mencatat 486 kasus DBD dan empat diantaranya meninggal dunia. ${ }^{8}$ Sebanyak 17 kasus terjadi di Kabupaten Ogan Komering Ulu Selatan (OKUS) dan 2 orang meninggal dunia. ${ }^{22}$ Upaya pengendalian nyamuk yang merupakan vektor penyakit ini perlu dilakukan selain dengan tindakan pengobatan terhadap penderita. Hal ini merupakan usaha yang penting untuk menurunkan kasus yang diakibatkan oleh nyamuk tersebut. ${ }^{17}$ Ikatan insektisida piretroid terhadap VGSC memunculkan fenomena yang dikenal dengan istilah knockdown, yaitu pergerakan yang cepat diikuti dengan kelumpuhan dan kematian. ${ }^{10}$ Mekanisme timbulnya resistensi terhadap piretroid adalah perubahan struktur VGSC di susunan syaraf pusat nyamuk sebagai target utama piretroid, sehingga terjadi penurunan afinitas terhadap insektisida. Salah satu titik mutasi Ae. aegypti yang tersebar luas di seluruh Asia yaitu V1016G dan F1534C. ${ }^{14}$

Titik mutasi F1534C resisten terhadap piretroid tipe I dan dilaporkan terdapat pada banyak negara Asia, Amerika Latin dan Afrika. ${ }^{11}$ Mutasi F1534C berada pada susunan TTC pada kodon pengkode fenil alanin berubah menjadi TGC (cysteine) sedangkan Mutasi V1016G adalah perubahan pada kodon pengkode valine menjadi glycine dengan transisi basa timin menjadi guanin pada susunan GTA menjadi GGA. $^{2}$

Ada tiga cara mendeteksi resistensi sintetik piretroid menurut WHO yaitu bioassay, biokimia dan molekuler. Keberhasilan mengendalikan vektor nyamuk tergantung pada kerentanannya terhadap insektisida. ${ }^{3}$

\section{Metode}

Penelitian ini merupakan penelitian deskriptif dengan uji di lapangan. Penangkapan larva Ae. aegypti akan dilakukan di semua Tempat 
Penampungan Air (TPA) yang berada di 100 buah rumah yang berlokasi di Kelurahan Pancur Pungah, Kecamatan Muara Dua, Kabupaten OKUS, Provinsi Sumatera Selatan. Populasi adalah seluruh larva dan pupa Ae. aegypti yang berasal dari TPA yang berada di Kelurahan Pancur Bunga, Kecamatan Muara Dua, Kabupaten OKUS Provinsi Sumatera Selatan. Pengambilan sampel dilakukan secara stratified random sampling yaitu cara mengambil sampel dengan mengkelompokkan rumah berdasarkan jumlah gang dan dilanjutkan dengan simple random sampling yaitu pengambilan sampel secara acak tanpa membagi kelompok kembali. Sampel yang diperoleh kemudian dibiakkan dan identifikasi secara purposive sampling yaitu berdasarkan pertimbangan sampel yang memenuhi kriteria inklusi dan eksklusi yang telah ditetapkan oleh peneliti. Pengambilan sampel dilakukan dengan mendatangi dan menyaring sesuai dengan kriteria inklusi dan eksklusi. Kemudian dilakan proses rearing untuk mendapatkan nyamuk dewasa betina generasi F1.

Selanjutnya dilakukan uji kerentanan nyamuk Ae. aegypti terhadap bahan aktif insektisida tersebut menggunakan metode standar WHO berbasis impregnated paper. Nyamuk betina dewasa Ae. aegypti non blood umur 3-5 hari dimasukkan ke dalam tabung uji yang dindingnya dilapisi impregnated paper berbahan aktif insektisida tersebut. Nyamuk dikontakkan selama 60 menit dan dicatat jumlah nyamuk yang pingsan (knockdown) tiap 10 menit. Pasca kontak, nyamuk di holding selama 24 jam dan dihitung jumlah yang mati dan hidup. Setelah pemaparan selama 1 jam pertama ditemukan bahwa $100 \%$ nyamuk uji tidak mengalami pingsan atau kematian dan hal tersebut berlanjut sampai pada pengamatan pada 24 jam kemudian.
Nyamuk hasil uji susceptibility kemudian dilakukan elektroforesis menggunakan alat Polymerase Chain Reaction (PCR).

Metode biomolekuler yang digunakan adalah sebagai berikut: total DNA diisolasi menggunakan metode Premiere Spesific Allel berdasarkan protokol penyelia. Sampel nyamuk hasil uji bioassay tadi dilakukan proses pooling dengan memisahkan nyamuk hidup dan nyamuk mati dalam satu tabung effendorf. Dipisahkan per individu dan ditambahkan larutan $\mathrm{PbS} 1 \mathrm{x}$ sebanyak $300 \mu \mathrm{l}$ dan divortex. Digerus dengan pestles. Sampel yang ada dalam tabung effendorf sebanyak 171 tabung effendord, diambil $30 \mu l$ tiap sampel sebanyak 10 sampel lalu dimasukkan ke dalam 1 tabung effendorf baru dan menjadi 1 pool sampel ekstraksi. divortex kembali kemudian disimpan di suhu $-4^{\circ} \mathrm{C}$ untuk sampel yang belum dilakukan ekstraksi DNA.

Tahap selanjutny dilakukan Isolasi dengan menggunakan DNA Wizard Purification Kit: Dimasukkan 600 ul nuclei lysis solution dalam tabung $1,5 \mathrm{ml}$, dinginkan dalam es dan dihomogenkan selama 10 detik. Ditambahkan 17,5 ul protein kinase ke dalam campuran, lalu diinkubasi selama $15-30$ menit dalam suhu $65^{\circ} \mathrm{C}$. Ditambahkan $300 \mu \mathrm{l}$ RNAase solution, dihomogenkan. Dan diinkubasi 15-30 menit pada suhu $37^{\circ} \mathrm{C}$. Didiamkan pada suhu ruangan selama 5 menit. Ditambahkan $200 \mu \mathrm{l}$ protein presipitation solution pada suhu ruang, kemudian atur waktu penggunaan vorteks pada kecepatan tinggi selama 20 detik. Didinginkan sampel pada es selama 5 menit. Disentrifugasi 13.000 rpm selama 4 menit. Protein precipitated akan berbentuk endapan pelet putih. Ditambahkan 600 $\mu \mathrm{l}$ isopranol ke dalam tabung $1,5 \mathrm{ml}$ baru. Dipindahkan supernatan ke dalam tabung yang telah diisi isopropanol tersebut. Diaduk perlahan sampai terbentuk benang putih. Disentrifugasi 
$13.000 \mathrm{rpm}$ selama 1 menit pada suhu ruang. DNA akan terlihat seperti benang putih. Dibuang supernatan, kemudian ditambahkan etanol $70 \%$ pada suhu ruang. Disentrifugasi $13.000 \mathrm{rpm}$ selama 1 menit pada suhu ruang. Diambil etanol pakai mikropipet, kemudian disaring sisa etanol menggunakan kertas saring. Dikeringkan pelet dalam suhu ruangan selama 10-15 menit. Dilarutkan pelet DNA dengan $100 \mu \mathrm{l}$ DNA dehydration solution. Diinkubasi sampel pada suhu $65^{\circ} \mathrm{C}$ selama 1 jam atau pada suhu $4^{\circ} \mathrm{C}$ selama 24 jam.

Dibuat campuran master mix yang terdiri dari Go Green Taq (Promega USA), 12,5 $\mu \mathrm{l}$ ddH2O, 3 $\mu \mathrm{l}$ DNA cetakan (template) serta primer oligonukleotida reverse (R) dan forward (F) masing-masing $1 \mu \mathrm{l}$, hingga volume total yang didapatkan $25 \mu \mathrm{l}$. Kemudian dilakukan amplifikasi DNA dengan menggunakan sepasang primer spesifik alel. Amplifikasi dilakukan dengan menggunakan mesin PCR Thermal cycler. Untuk menentukan suhu optimal amplifikasi, sebelumnya akan dilakukan optimasi terlebih dahulu. Secara umum siklus PCR meliputi predenaturasi, denaturasi, annealing, extension, dan final extension

\section{Hasil dan Pembahasan}

Kabupaten OKUS merupakan wilayah dataran tinggi yang berbukit-bukit dengan ketinggian antara 45 sampai 1.643 mdpl. Kabupaten OKUS yang terbentuk pada tahun 2004, memiliki wilayah administrasi yang terbagi 19 kecamatan. $^{12}$ Sebagian besar wilayah kecamatan merupakan dataran tinggi. Hanya 6 kecamatan saja yang relatif datar, yaitu Kecamatan Muaradua, Buay Rawan, Buay Sandang Aji, Tiga Dihaji, Buay Runjung, dan Runjung Agung.Wilayah tertinggi di Kabupaten Ogan Komering Ulu Selatan adalah Gunung Seminung di Kecamatan Banding Agung, dengan ketinggian 1.888 meter dari permukaan laut. Secara administratif yaitu Kecamatan Muaradua sebagai ibu kota Kabupaten OKUS terdiri dari 9 (sembilan) desa, dan 5 (lima) kelurahan dengan luas wilayah $26.195 \mathrm{Ha}$ atau $261,95 \mathrm{~km}^{2} .{ }^{1}$

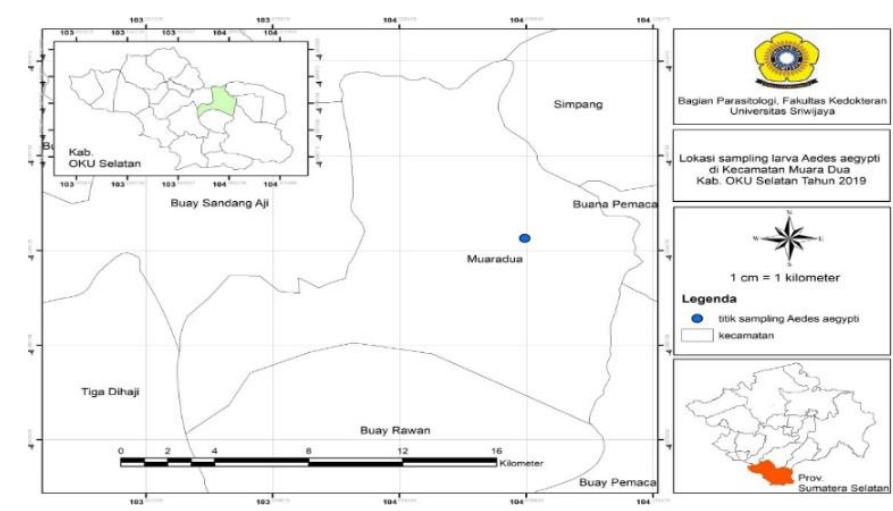

Gambar 1. Titik Lokasi Pengambilan Sample Larva Aedes aegypti di Kecamatan Muara Dua Kabupaten OKUS 
Penelitian dilakukan di 100 rumah penduduk di RT 05 dan RT 06 Kelurahan Pancur Pungah Kecamatan Muara Dua Kabupaten OKUS Provinsi Sumatera Selatan yang dapat dilihat pada Gambar 1. Dari 100 rumah yang didatangi, semuanya memiliki Tempat Penampungan Air (TPA) yang dapat dijangkau dan sebanyak 35 rumah ditemukan jentik nyamuk berupa larva dan atau pupa.

Dari 100 buah rumah yang diteliti, didapatkan hasil uji suscpetibility dengan jumlah kematian nyamuk setelah dilakukan uji

susceptibility selama 24 jam adalah 10,5\% (Tabel 1.) . Sesuai dengan kriteria WHO (2016) sebagai berikut:

a). Konfirmasi resisten jika kematian $<90 \%$.

b). Kemungkinan resisten/toleran jika jumlah kematian $90-97 \%$

c). Dikatakan rentan terhadap insektisida jika jumlah kematian 98-100\%. dapat diketahui bahwa nyamuk pada lokasi penelitian ini telah mengalami resisten terhadap permethrin $0,75 \%$. 19

Tabel 1. Hasil Uji Nyamuk Ae. aegypti Betina Terhadap Permethrin 0,75\%

\begin{tabular}{ccc}
\hline Perlakuan & Jumlah nyamuk & Jumlah nyamuk yang mati setelah 24 jam \\
\hline 1 & 23 & 2 \\
2 & 25 & 3 \\
3 & 25 & 3 \\
4 & 24 & 9 \\
5 & 25 & 0 \\
Kontrol I & 25 & 0 \\
Kontrol II & 24 & 18 \\
\hline Total & 171 & 3 \\
\hline
\end{tabular}

Hasil penelitian ini sesuai dengan temuan sebelumnya bahwa nyamuk Ae. aegypti menunjukkan hasil bahwa telah $A$ e. aegypti di Semarang, Banyumas, Tegal, Blora, Surakarta, Magelang, Yogayakarta, Sleman, Bantul dan Salatiga telah resisten terhadap permetrin 0,75\% dengan prosentase kematian nyamuk 15\% $65 \% .{ }^{21}$ Penelitian lain menyatakan bahkan status resisten juga ditemukan di Provinsi Jawa Tengah terhadap insektisida golongan piretroid dengan bahan aktif permethrin $0,75 \%$ dan deltamethrin 0,05\%, namun masih sensitif terhadap golongan organofosfat dengan bahan aktif malathion 5\%. Angka kematian atau mortalitas untuk golongan piretroid kurang dari $80 \%$, yaitu $17 \%$ dan $67 \%$, sedangkan untuk golongan organofosfat mencapai $100 \% .^{18}$

Ada 3 faktor yang mempengaruhi status kerentanan beberapa serangga termasuk nyamuk, yaitu: faktor genetik yaitu berupa gen yang menyandi pembentukan enzim esterase, yang dapat menyebabkan resistensi serangga terhadap insektisida baik organofosfat atau piretroid. Faktor genetik lainnya seperti adanya gen knockdown resistence (kdr) sehingga serangga resisten terhadap DDT. Selanjutnya faktor biologis, meliputi biotik karena pergantian generasi melalui perkawinan monogami atau poligami. Terakhir faktor operasional, meliputi bahan kimia yang digunakan dalam pengendalian 
vektor baik golongan insektisida yang memiliki kesamaan target dan sifat insektisida yang pernah digunakan, serta aplikasi insektisida tersebut di lapangan meliputi cara aplikasi, frekuensi dan lama penggunaan. ${ }^{15}$

Berdasarkan kenyataan tersebut kemungkinan resistensi terjadi karena penggunaan insektisida dari golongan yang sama secara berkelanjutan terutama dari insektisida rumah tangga yang penggunaannya hampir setiap hari. Kematian nyamuk pada tiap uji pada tiap daerah berbeda menunjukkan hasil berbeda. Selain penggunaan insektisida baik dari program maupun rumah tangga untuk penanggulangan nyamuk dewasa, keberadaan jentik nyamuk di lingkungan masyarakat juga turut mempengaruhi peningkatan kasus DBD ataupun status resistensi di kabupaten/kota tersebut. ${ }^{16}$

Kemudian berdasarkan hasil elektroforesis untuk gen VGSC mutasi titik F1534C terdapat 2 pita yang terbentuk pada pada titik F1534C yaitu dengan panjang 232 bp dan 368 bp. Panjang pita 368 bp menggambarkan kontrol pita yang harus ada di titik tersebut sedangkan panjang pita 232 bp menggambarkan titik F1534C tanpa terjadinya mutasi yang dapat dilihat pada Gambar 2. Hal ini menunjukkan bahwa nyamuk Ae. aegypti di tempat penelitian belum mengalami mutasi pada titik F1534C.

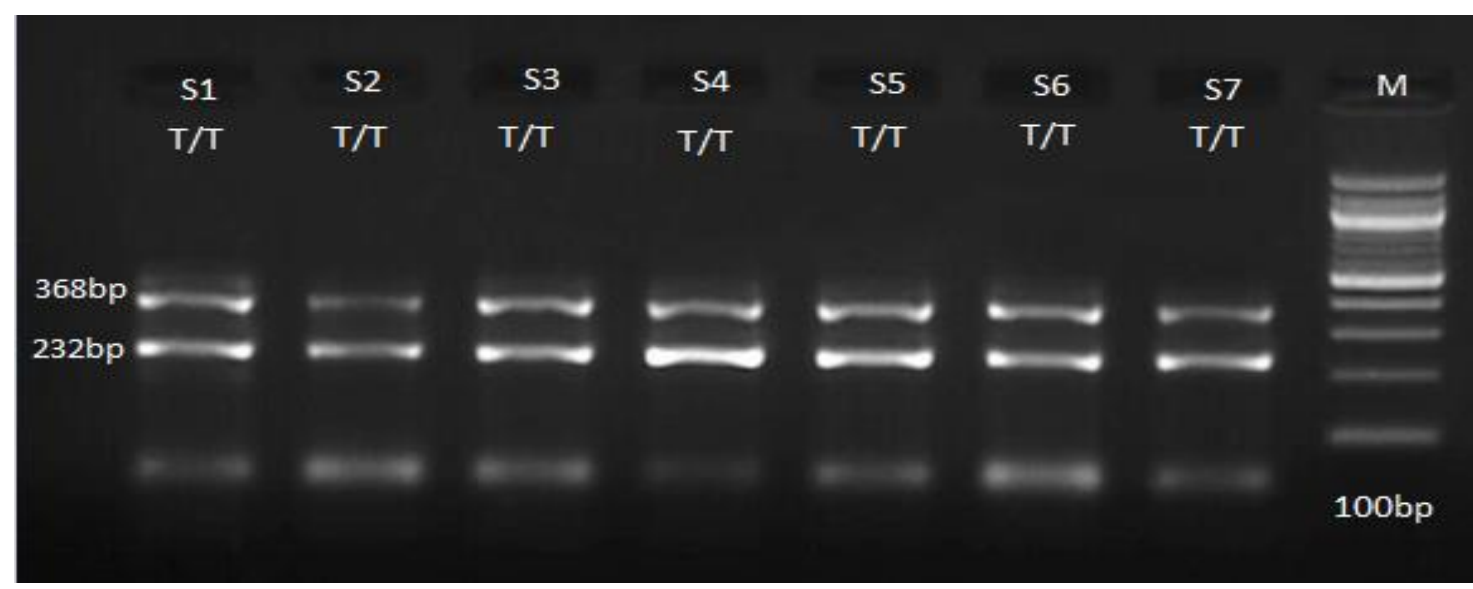

Gambar 2. Hasil Elektroforesis Gen VGSC Titik F1534C pada Nyamuk Aedes aegypti di Kelurahan Pancur Pungah

Mutasi adalah kejadian berubahnya asam nukleat yang berpengaruh pada ekspresi protein sebagai pembentuk sel. Dalam pemeriksaan laboratorium mutasi dapat dilihat dengan menemukan perubahan asam amino. Secara invitro, mutasi dapat dipicu dengan pemberian insektisida dosis non letal. Untuk mengetahui adanya mutasi yang menimbulkan resistensi insektisida, maka digunakan primer dengan susunan dan panjang basa yang spesifik. Perubahan fenilalanin menjadi sistein pada kodon
1534 ditunjukkan dengan berubahnya susunan TTC menjadi TGC yaitu pada domain III subunit 6. ${ }^{11,6}$ Pada penelitian ini tidak dilakukan sequencing untuk melihat urutan basa.

Pada penelitian di Australia diatas memperlihatkan bahwa terjadi mutasi, baik yang homozigot maupun heterozigot yaitu berupa mutasi pada kodon 1534 mengubah fenilalanin menjadi sistein. ${ }^{4}$ Sedangkan pada penelitian yang dilakukan di Kota Chiang Mai, Thailand menunjukkan sering terjadi mutasi homozigot 
C1534. Sehingga tidak terekspresinya gen mutasi pada penelitian sekarang karena titik mutasi bukan berada pada titik tersebut. ${ }^{11}$ Pada penelitian lain memperlihatkan tidak menunjukkan adanya perubahan mutasi pada hasil PCR dan sequencing di kodon $1534 .^{6}$

Tidak terjadinya mutasi pada kodon 1534 di Kota Jiaxiang juga dialami oleh peneliti lain dan mencoba menilai hubungan antara mutasi $\mathrm{kdr}$ pada kodon 1534 dan resistensi pada alel F1534S dan F1534L dianalisis secara terpisah. Mutasi F1534S secara bermakna dikaitkan dengan resistensi deltamethrin, tetapi mutasi F1534L tidak menunjukkan perbedaan yang signifikan antara kelompok $\mathrm{R}$ dan $\mathrm{S} .{ }^{9} \mathrm{Hal}$ inilah menjadi dasar bahwa tidak terjadinya mutasi pada titik F1534C tetapi ada kemungkinan bisa terjadi pada titik lainnya.

\section{Kesimpulan}

Adapun kesimpulan yang diperoleh dari penelitian ini yaitu telah terjadinya resistensi pada uji susceptibility dengan jumlah kematian 10,5\%, namun tidak adanya titik mutasi yang terjadi pada gen VGSC mutasi titik F1534C pada Aedes aegypti di Kelurahan Pancur Pungah, Kecamatan Muara Dua, Kabupaten Ogan Komering Ulu Selatan. Memerlukan penelitian lebih lanjut menggunakan primer lain yang bekerja pada titik mutasi yang diketahui berhubungan dengan kejadian resistensi sintetik piretroid. Penelitian lanjutan untuk mengetahui apakah telah terjadi mutasi pada tingkat enzim.

\section{DAFTAR PUSTAKA}

1. BPS OKUS. 2019. Statistik Daerah Kabupaten Ogan Komering Ulu Selatan Tahun 2019. Katalog BPS : 1101002.1608

2. Ghiffari, A. dan H. Fatimi. 2012. Deteksi Mutasi Gen Voltage Gated Sodium Channel Aedes aegypti Sebagai Penanda Resistensi Inskestisida Sintetik Piretroid. Fokus Utama Vol 1(1): 12-24.

3. Ghiffari, A., H. Fatimi, dan C. Anwar. 2013. Deteksi Resistensi Insekstisida Sintetik Piretroid pada Aedes aegypti (L.) Strain Palembang Menggunakan Teknik Polymerase Chain Reaction. Aspirator Vol.5 (2): 3744.

4. Harris, A.F., S. Rajatileka and H. Ranson. 2010. Pyrethroid Resistance in Aedes aegypti from Grand Cayman. Am. J.Trop. Med. Hyg. 83(2): 277-284.

5. Jamil, A. I. 2019. Kemenkes: Per 1 Februari 2019, Ada 15.132 Kasus DBD di Indonesia. (https://www.inews.id/news/nasional/kemenkes-per-1-februari-2019-ada-15-132-kasus-dbd-diindonesia, diakses pada tanggal 20 Maret 2020 pk. 19.30 WIB).

6. Kamgang, B., T. A. W. Bahun, A. P. Yougang, A. Lenga and C. S. Wondji. 2020. Constrasting Resistance Patterns To Type I and II Pyrethtorids In Two Major Arvobirus Vectors Aedes aeygpti and Aedes Albopictrus in the Republic of the Congo, Central Africa. Infectious Diseases of Poverty Vol. 9 (23): 1-10.

7. Kemenkes RI. 2010. Demam Berdarah Dengue. Buletin Jendela Epidemiologi Vol.2 (1) : 1-48.

8. Kurniawan W. 2019. Dinkes Sumsel Catat 486 Kasus dan Empat Warga Meninggal Dunia Akibat DBD. (http://palembang.tribunnews.com/2019/02/06/dinkes-sumsel-catat-486-kasus-dan-empat-wargameninggal-dunia-akibat-dbd-berikut-data-lengkapnya, diakses pada tanggal 19 Agustus 2019 pk. 20.00 WIB).

9. Liu, H., L. Liu, P.Cheng, L. Yang, J. Chen, Y. Lu. H Wang, X. Chen, and M. Gong. 2020. Bionomics and Insecticide Resistance of Aedes albopictus in Shandong, a High Latitude and High-Risk Dengue Transmission Area in China. Parasites \& Vectors Vol. 13(11): 1-9.

10. Martins, A.J., R.M.M.A. Lins, J.G.B. Linss, A.A. Peixoto, and D. Valle. 2009. Voltage-Gated Sodium Channel Polymorphism and Metabolic Resistance in Pyrethroid -Resistant Aedes aegypti from Brazil. Am. J. Trop. Hyg Vol. 81 (1): 105-115.

11. Plernsub, S., J. Saingamsock, J. Yanola, N. Lumjuan, P.Tippawangkosol, K. Sukantason, C. Walton and P. Somboon. 2016. Additive Effect of Knockdown Resistance Mutations S989P, V1016G and F1534C, in A Heterozygous Genotype Conferring Pyrethroid Resistance in Aedes aegypti in Thailand. Plernsub et al. Parasite \& Vectors Vol.9 (1): 417-424.

12. Portal OKUS. 2019. Portal Resmi Ogan Komering Ulu Selatan Serasan Seandaan. (https://okuselatankab.go.id/letak-geografis/, diakses pada tanggal 5 Januari 2020 pk.10.00 WIB). 
13. Prasetyaningsih, Sari, Prasetya H, and Wulandari. 2018. "Potensi Etnomedicine Daun Ubi Jalar Ungu (Ipomoea Batatas) sebagai Obat Demam Berdarah." Prosiding Seminar Nasional Vokasi Indonesia 6 (November): 6-11.

14. Purwaningsih, S.R. Umniyati, dan B. Mulyaningsih. 2019. Combined Target Site Vgsc Mutations Play A Primary Role In Pyrethroid Resistant Phenotypes Of Aedes aegypti As Dengue Vector From Palu City, Central Sulawesi. Indonesian Journal of Tropical and Infectious Disease Vol. 7 (5): 93-98.

15. Pradani, F.Y., M. Ipa, R. Marina, dan Y. Yuliasih. 2011. Status Resistensi Aedes aegypti dengan Metode Suscepbility di Kota Cimahi Terhadap Cypermethrin. Aspirator Vol.3 (1): 18-24.

16. Rahayu, N., S. Sulasmi, dan Y. Suryatinah. 2017. Status Kerentanan Aedes aegypti Terhadap Beberapa Golongan Insektisida di Provinsi Kalimantan Selatan. JHECDs Vol. 3 (1): 56-62.

17. Rahmawati, E., U.K. Hadi, dan S. Soviana. 2014. Keanekaragaman Jenis dan Perilaku Menggigit Vektor Malaria (Anophles spp.) di Desa Lifuleo Kecamatan Kupang Barat, Kabupaten Kupang, Nusa Tenggara Timur. Jurnal Entomologi Indonesia Vol.11 (2): 53-64.

18. Sayono dan U. Nurullita. 2016. Situasi Terkini Vektor Dengue (Aedes aegypti) di Jawa Tengah. KEMAS Vol. $11(2): 96-105$.

19. WHO. 2016. Test procedures for insecticide resistance monitoringinmalaria vector mosquitoes. ((http://www.who.int/malaria, diakses pada tanggal 15 Maret 2020 pk. 20.00 WIB).

20. WHO. 2019. Dengue and Server Dengue. (https://www.who.int/news-room/fact-sheets/detail/dengue-andsevere-dengue, diakses pada tanggal 20 Maret 2020 pk. 18.00 WIB).

21. Widiarti, B. Heriyanto, D.T. Boewono, U.W. Mujiono, Lasmiati, dan Yuliadi. 2011. Peta Resistensi Vektor Demam Berdarah Dengue Aedes aegypti Terhadap Insektisida Kelompo Organofosfat, Karbamat, Pyrethroid di Propinsi Jawa Tengah dan Daerah Istimewa Yogyakarta. Bul.Penelit.Kesehat. Vol. 39 (4): 176-189.

22. Windy, S. 2019. Awas! DBD Mulai Serang Warga OKU Selatan. (https://sumeks.co/awas-dbd-mulai-serangwarga-oku-selatan/, diakses pada tanggal 19 Agustus 2019 pk. 18.00 WIB). 